\title{
Effect of Promoting Diazotrophic Bacteria and Seaweed Extract Formula on Growth, Yield and Quality of Pea (Pisum Sativum L.) Plants
}

\author{
Gehan A. Elsharkawy ${ }^{1}$, Hanaa S. Hassan ${ }^{1}$ and Hassan A.H. Ibrahim ${ }^{2}$
}

\begin{abstract}
Two field experiments were carried out at the Experimental farm, Faculty of Agriculture, Alexandria University during 2017 and 2018 winter seasons. The aim of the current study was to investigate the effects of different bio-fertilizer types and seaweed extract formula ( $0,5,10 \mathrm{mll}^{-1}$ ) on vegetative growth characters, total pods yield and its components as well as chemical constituents of green seeds of the pea cultivar "Balmoral". The results indicated that plant height, foliage fresh weight, foliage dry matter, number of branches plant ${ }^{-1}$, total yield (ton fed. ${ }^{-1}$ ), $N$, protein and $K$ contents in green seeds were significantly and positively affected by different bio-fertilizer types and the seaweed extract . The highest total pods yield fed. ${ }^{-1}$ obtained by foliar application of seaweed extract at the rate of $10 \mathrm{mll}^{-1}$ in both growing seasons. Addition of biofertilizer (1) combined with foliar application of seaweed extract at the rate $10 \mathrm{mll}^{-1}$ gave the highest growth characters and total yield fed. ${ }^{-1}$ with the highest protein content of green seeds of pea plants, in both growing seasons.
\end{abstract}

Keywords: Pea, bio-fertilizer, promoting bacteria, seaweed extract, growth, yield.

\section{INTRODUCTION}

Pea (Pisum sativum L.) is one of the most important legume vegetable crops in the world that growing in the winter season. The green seed of pea is commonly used in human diet where it is rich in protein, carbohydrates, antioxidant, vitamin A and C. Also, it has high levels of amino acids, minerals and dietary fibers(Mishra, 2014). Economically pea is a dominate export and cash crop in world trade and represents about $40 \%$ of the total trading in legumes for both fresh use and processing (Oram \& Agcaolili, 1994).

The use of mineral fertilizers in the vegetable crops production for long periods led to the spread of many diseases, which afflict humans as well as they cause pollution of the environment and water. Therefore, it was necessary to have natural tools and strategies for lowering use of chemical fertilizers in the vegetable crops production without having any effects on the environment and obtaining a good crop and quality. In order to prevent or, at least reduce the huge amounts of mineral nitrogen fertilizers applied by growers, aiming to increase the quantity of yield, without any care of its risk which led to plant and soil pollutions with different elements.

The application of bio-fertilizers is economically important to reduce the cost of mineral fertilizers and ecologically to avoid environmental pollution. Many diazotrophic bacteria produce and, also, secrete phytohormones like auxin, citokinins and gibberellins and thereby enhance growth of roots and shoots (Jagnow et al., 1991).

Rhizobium bacteria are among the most beneficial soil bacteria, which known as bio-fertilizer, whose members are most notable for their ability in $\mathrm{N}_{2}$ fixation, generate plant growth promoting substances, and because of the existence of technology having the potential to mass production of inoculants (Saghafi et al., 2018).

Bio- fertilizers play a very important role in improving soil fertility by fixing atmospheric nitrogen through the living symbiotic with plant roots; solubilize insoluble soil phosphates and produces plant growth substances in the soil (Zaghloul et al., 2015)

Many studies indicated that seaweed extract has many components like minerals, carbohydrates, amino acids, many of vitamins, betaines and growth regulators, which affect on metabolism of plants leading to enhance vegetative growth and total yield of vegetable crops. Also, seaweed extract applications especially at early stage of plant growth and establishment, improve crop performance and yield elevated resistance to biotic and abiotic stress, and enhanced postharvest (Norrie and Keathley,2006). Today many of seaweed extracts used as a fertilizer and number of seaweed product used in agriculture(khan et al., 2009 and Ramya et al.,2015).Vegetable crop cultivation using seaweed extract as a fertilizers has increased germination and growth in legume plants (Kavipriya et al., 2011). Several investigations support different aspects of potential macro algal applications in agriculture. Currently, seaweed extracts are the new type of products used in plant cultivation. The sources of seaweed

DOI: 10.21608/ASEJAIQJSAE.2019.30240

${ }^{1}$ Depertment of Vegetable Crops, Faculty of Agriculture,

Alexandria University.

${ }^{2}$ Marine Environment Division, National Institute of

Oceanography \& Fisheries (NIOF), Alexandria Branch.

Received March 3, 2019, Accepted March31, 2019 
extracts are different species of marine algae which seem to be valuable and not wholly discovered biological material (Khan et al., 2009).

Finding environmentally safe methods became an important task that might be achieved through specific treatments.

For achieving these aims this study was to identify how respond the growth, yield and quality of pea plants to bio-fertilizers and seaweed extract .

\section{MATERIAL AND METHODS}

Two field experiments were carried out, during the winter seasons of 2017and 2018, at the Experimental Station Farm of the Faculty of Agriculture Abies, Alexandria University; Alexandria, Egypt. To study the effects of four bio-fertilizers ( Bio.1 ,Bio.2, Bio. 3 and Bio.4) in addition to control and three concentrations of seaweed extract $\left(0,5\right.$ and $\left.10 \mathrm{ml} \mathrm{l}^{-1}\right)$ as well as its interactions effect on the growth, yield and quality of pea plants.

Before execute the trials, soil samples were randomly collected up to $30 \mathrm{~cm}$ depth. Then, some physical and chemical properties of the soil of the two experimental sites, were determined according to methods described by (Page, 1982), and the results of analysis soil are presented in Table (1).

The seeds of Balmoral cultivar of pea were sowing in the first week of October , in both seasons. All seeds were sown in hills $15 \mathrm{~cm}$ apart on the two sides of rows.

\section{Treatments Preparation:}

The promoting bacteria that used as a bio-fertilizers were:-

1- Control (0), without bio-fertilizers

2- Bio-fertilizer (1), it is containing multi-strains of $P$ and $\mathrm{N} 2$ fixing bacteria of genera Bacillus as fixing of $\mathrm{P}$ and Azotobacter, Azospirllum and Rhizobium as fixing of $\mathrm{N}$.

3- Bio-fertilizer (2), it is containing multi- strains of $\mathrm{N} 2$ fixing bacteria of Azotobacter .

4- Bio-fertilizer (3), it was containing Azotobacter chroococcum and Azospirillum barsilense.

5- Bio-fertilizer (4), it was containing multi- strains of N2 fixing bacteria of Colstriedum, Azospirllum and Rhizobium as a source of $\mathrm{N}$.

Table 1. Soil physical and chemical properties of the experimental sites in the two growing seasons of 2016/2017 and 2017/2018*

\begin{tabular}{|c|c|c|}
\hline $\begin{array}{ll}\text { Properties } & \text { Seasons } \\
\end{array}$ & $2016 / 2017$ & $2017 / 2018$ \\
\hline \multicolumn{3}{|l|}{ Physical properties } \\
\hline Sand \% & 34.20 & 34.20 \\
\hline Silt \% & 24.20 & 24.60 \\
\hline Clay \% & 41.60 & 41.20 \\
\hline Soil texture & Clay loam & Clay loam \\
\hline \multicolumn{3}{|l|}{ chemical properties } \\
\hline $\mathrm{pH}$ & 7.90 & 8.00 \\
\hline E.C. $\left(d S . m^{-1}\right)$ & 3.06 & 3.01 \\
\hline \multicolumn{3}{|l|}{ Soluble cations (m.eq $\left.\mathbf{l}^{-1}\right)$} \\
\hline $\mathrm{Ca}^{++}$ & 1.70 & 1.60 \\
\hline $\mathbf{M g}^{++}$ & 1.50 & 1.40 \\
\hline $\mathbf{N a}^{+}$ & 1.60 & 1.80 \\
\hline $\mathbf{K}^{+}$ & 0.36 & 0.38 \\
\hline \multicolumn{3}{|l|}{ Soluble anions (m.eq $\left.\mathrm{l}^{-1}\right)$} \\
\hline $\mathrm{CO}_{3}^{--}$ & Zero & Zero \\
\hline $\mathrm{HCO}_{3}^{-}$ & 1.30 & 1.24 \\
\hline $\mathrm{Cl}^{-}$ & 1.20 & 1.10 \\
\hline $\mathrm{SO}_{4}^{--}$ & 3.18 & 3.15 \\
\hline Available $\mathbf{P}$ (ppm) & 0.33 & 0.30 \\
\hline
\end{tabular}

\footnotetext{
* These analysis were carried out at the central laboratory, Faculty of Agriculture, Alexandria University.
} 
The preparation of the bio- fertilizer inoculums were done at the laboratory of bacterial studies, plant pathology department, Alexandria University. Inoculums of the different bacterial genus were prepared by sub-culturing their mother cultures on nutrient agar in kolle flasks for 72 hrs., after which the heavy growth was then scratched and transferred to sterile tap water and thoroughly mixed. The prepared inoculums were then used to inoculate seeds. The bio-fertilizers were added at two split doses with fresh inoculums the first dose was applied at sawing, the second was after twenty days from sawing. All biofertilizer inoculums were added at rate $\left(10^{3}-10^{4}\right.$ cells/ $\mathrm{ml}$ "16 litter/ ha $\left.{ }^{-1 "}\right)$.

\section{Preparation of Seaweed Extract Formulation}

Samples of common algae (Ulva lactuca, Ulva faciata and Peterocladia caplicia) were collected from the Eastern Harbor located at Alexandria, Egypt during summer 2017. The fresh samples were washed with seawater at the sampling site to remove the adhered sediments and impurities then put in polyethylene bags. Quick rinsing of the alga with tap water was carried out in the laboratory on the same day to get rid of the remaining impurities and epiphytes. Algal samples were air-dried in the shade at room temperature on absorbent paper, then cut into very small pieces of about $2 \mathrm{~mm}$ size. However, microscopic identification of the investigated algae was carried out according to Aleem (1993) and Braune (2008).

The extraction step was treated with ethanol $70 \%$ by soaking the material in the solvent $(1: 10, w / v)$ on a rotary shaker at $150 \mathrm{rpm}$ at room temperature for $72 \mathrm{~h}$. The extracts from consecutive soakings were pooled and filtered using filter paper (Whatman No. 4), and then they obtained filtrate was air dried to evaporate the solvent.

On the other side, humic acids were isolated from the samples according to Pempkowiak et al. (1994) and the final solution actually contains both humic and fulvic acids.

The formulation of seaweed extracts and humic substances was designed as follows:

1. The crude extracts were firstly mixed with equal ratios.

2. The mixture was added to the humic substances in the solution form and stirred well in a ratio of $3: 1$ $\mathrm{v} / \mathrm{v}$.

3. This formula was stored at $-20^{\circ} \mathrm{C}$ until usage.
Table 2.Chemical composition of seaweed extracts formulation

\begin{tabular}{|c|c|}
\hline Parameter & Value \\
\hline Odor & $\begin{array}{l}\text { Humic to seaweed- } \\
\text { like odor }\end{array}$ \\
\hline Color & Dark brown \\
\hline Texture & Dense (near to oily) \\
\hline $\begin{array}{l}\text { Humus (Humic acid }+ \text { fulvic } \\
\text { acid) }\end{array}$ & $10 \%$ \\
\hline Alginic acid & $10 \%$ \\
\hline Suspended matter & Lower than $15 \%$ \\
\hline Total protein & $1 \mathrm{gl}^{-1}$ \\
\hline Total carbohydrates & $30 \%$ \\
\hline Total lipids & $5-7 \%$ \\
\hline Vitamin C & $4 \mathrm{mgl}^{-1}$ \\
\hline $\mathrm{P}$ & $111.6 \mathrm{mgl}^{-1}$ \\
\hline $\mathrm{K}$ & $7.56 \mathrm{mgl}^{-1}$ \\
\hline $\mathrm{Mg}$ & $25.3 \mathrm{mgl}^{-1}$ \\
\hline $\mathrm{Fe}$ & $120.1 \mathrm{mgl}^{-1}$ \\
\hline $\mathrm{Mn}$ & $60.0 \mu \mathrm{gl}^{-1}$ \\
\hline $\mathrm{Zn}$ & $42.0 \mu \mathrm{gl}^{-1}$ \\
\hline Ash & $10 \%$ \\
\hline $\mathrm{pH}$ & $5-6$ \\
\hline
\end{tabular}

\section{Experimental layout and treatments}

The experimental layout was a split plots system in a Randomized Complete Blocks Design with three replications. Each replicate included 15 treatments, which were the combinations of four promoting bacteria (bio-fertilizers) as well as control treatment and three rates of seaweed extract $\left(0,5,10 \mathrm{ml} \mathrm{l}^{-1}\right)$ that used as foliar application. The bio-fertilizers were, randomly, arranged in the main plots, while seaweed extract rates were, randomly, distributed in the sub-plots. Each subplot consisted of three ridges; each ridge was $4 \mathrm{~m}$ length and $0.7 \mathrm{~m}$ width. The inoculation process by biofertilizes was carried out by mixing the bacteria with pea seeds, which wetted by a small amount of water and sugar before 30 minutes from sowing. Seeds of the uninoculation (control treatment) were wetted by a small amount of distal water and sugar. However, seaweed extract was used as a foliar application at three times, after 20, 30 and 40 days from sowing with adding Tween $20(0.5 \%)$ as a wetting agent. The untreated plants (control) were sprayed with tap water (according to Dawa, et al., 2014).

The experimental soil in the two growing seasons was received $40 \mathrm{~kg} \mathrm{fed}^{-1}$ calcium superphosphate $\left(\begin{array}{ll}15.5 \% & \mathrm{P} 2 \mathrm{O} 5)\end{array}\right)$ as one dose before sowing. Ammonium sulfite $(20.5 \% \quad \mathrm{~N})$ at $30 \quad \mathrm{~kg}$ fed-1 
(activity dose) which was added after 15 days from sowing and Potassium sulphate $(48 \% \mathrm{~K} 2 \mathrm{O})$ at $50 \mathrm{~kg}$ was added at two times, i.e., after 30 and 50 days from sowing. Other recommended agricultural practices were followed as commonly used in the commercial production of pea plant outlined by the Ministry of Agriculture and the Reclamation-Arab Republic of Egypt.

\section{Data Recorded}

\section{Vegetative growth characters}

At the first time of harvest( after 70 days from sowing ), the data of vegetative growth characters were determined of the five plants randomly chosen from first row of each sub-plot to measure the plant height $(\mathrm{cm})$, the number of branches, foliage fresh weight $(\mathrm{gm})$ plant ${ }^{-1}$ and dry matter of plant foliage $(\%)$.

\section{Yield and its components}

The plants of second row of each sub plot were saved to find the number of pods plant ${ }^{-1}$, the average weight of pods plant ${ }^{-1}$, number of seed pod $^{-1}$, shelling ratio (\%) and total pods yield fed ${ }^{-1}$ (ton) characters. .

\section{Chemical constituents of green seed}

Minerals contents of green seeds (\%) were determinate according to the methods mentioned by Evenhuis and Dewaard (1980), and Murphy and Riley (1962). The protein percentages in green seeds were calculated by multiplying nitrogen content by 6.25 .

\section{Statistical analysis}

All obtained data were statistically analyzed using Co-Stat Software (2004), a computer program for statistics. Duncan's multiple range tests was used to compare the differences among the means of the different treatments as elucidated by Steel and Torrie (1984).

\section{RESULTS AND DISCUSSION}

\section{Vegetative Growth}

The results concerning the differences between the two studied factors as well as their interactions on vegetative growth characters of peas plants which included plant height, number of branches, foliage fresh weight and dry matter of plant are shown in Figures (1, 2) and Table (3). The results clarified the presence of significant increment on the vegetative growth characters of pea as a result to use bio-fertilizer types, in both growing seasons. Generally, inoculation pea seeds by different bio-fertilizer treatments resulted in higher vegetative growth characters compared with the control treatment, in both seasons. The highest values for all vegetative growth characters were obtained from using treatment bio 1 which is a mixture of many bacterial strains. While, the greatest foliage dry matter (\%) for peas plants was obtained from control treatment .Similar results were reported by (Rather et al. 2010; Sarg and Hassan,2003 and Solieman et al. 2003) on pea plant, that inoculation of pea seeds with bio-fertilizer, where there was significantly increase in vegetative growth characters compared to the un inoculated one. This can be clarified based on bio-fertilizer has dramatically influenced on bio control in the rhizosphere, that could be due to the action of one or more of the growth promoting substances especially auxin and gibberellins.

Fig (2) also indicated that foliar spraying of pea plants with seaweed extract significantly increased the mean values of all these parameters as compared with the control treatment. Spraying pea plants with $10 \mathrm{ml} \mathrm{l}^{-1}$ of seaweed extract gave the highest values of all vegetative growth parameters, in both seasons, with exception in the case of the foliage dry matter (\%), in two seasons. Growth enhancement of pea plants by foliar application of seaweed extract may be due for its high contents from macro and micro elements, amino acids, vitamins, cytokinins and auxins. These growth hormones may be play an imperative role in enhancement of cell size and cell division and their presence together they complement each other, where the Cytokinins are effective in shoot formation and auxin in root development, while micronutrients improve the soil health (Ordog et al. 2004 and Ramya et al. 2015).

With respect to the interaction effects between biofertilizer inoculation and foliar application of seaweed extract, the obtained results illustrated in (Table 3) reflected, in general, that the combined treatment between Bio1, which contained multi-strains of $\mathrm{P}$ and $\mathrm{N}_{2}$ fixing bacteria and seaweed extract concentration of 10 $\mathrm{ml}^{-1}$ produced the highest mean values for all vegetative parameters, in the two seasons, except, the values of foliage dry matter $(\%)$. 


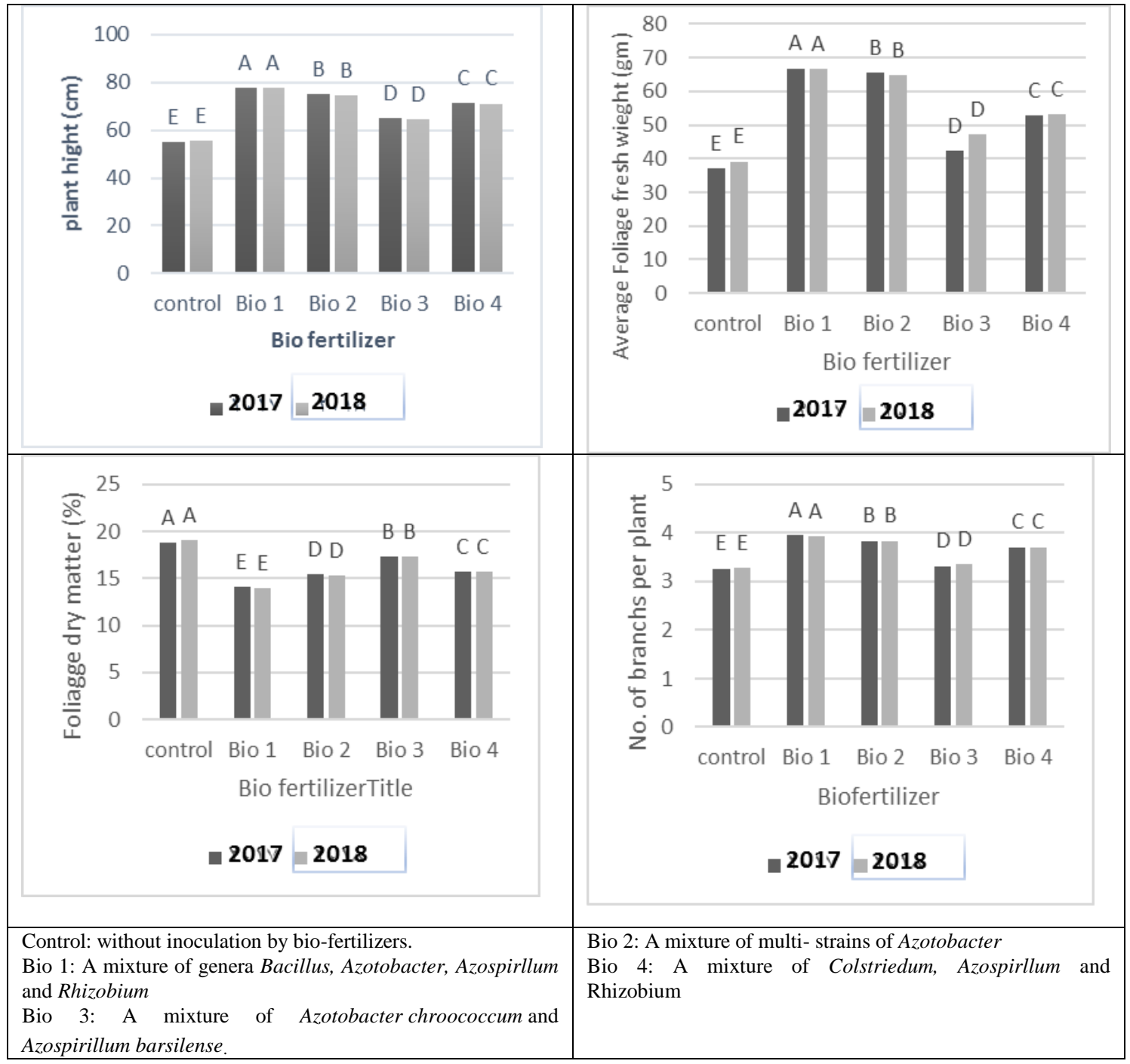

Fig. 1. Effect of bio fertilizer on vegetative growth characters in winter seasons 2017 and 2018 


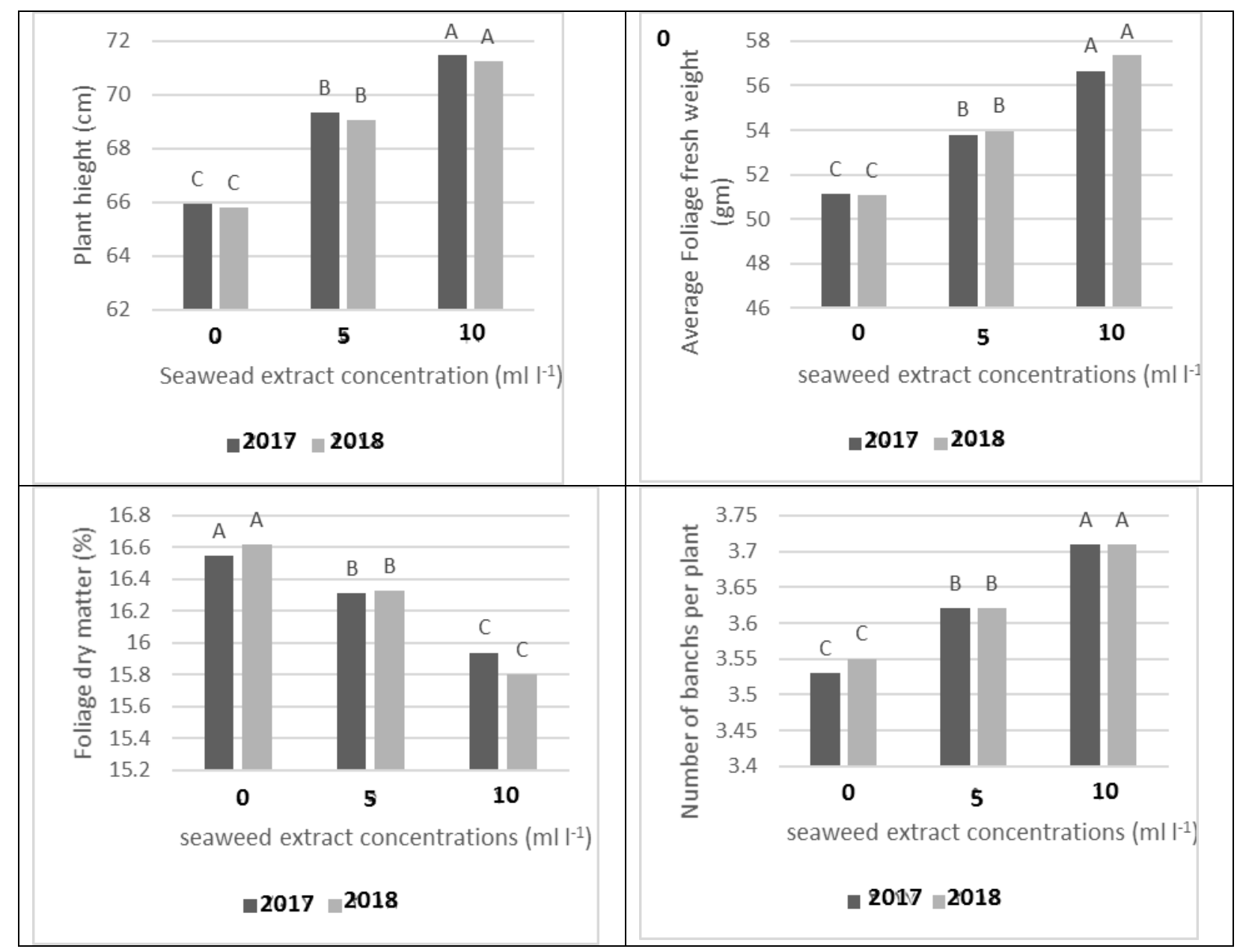

Fig.2. Effect of seaweed extract concentrations on vegetative growth characters in winter seasons 2017 and 2018 
Table 3.The interaction effects between bio fertilizer and seaweed extract on vegetative growth characters in winter seasons 2017 and 2018

\begin{tabular}{|c|c|c|c|c|c|}
\hline \multicolumn{2}{|c|}{ Treatments } & \multirow{2}{*}{$\begin{array}{l}\text { Plant height } \\
(\mathrm{cm})\end{array}$} & $\begin{array}{c}\text { Foliage fresh } \\
\text { weight (g) }\end{array}$ & \multirow{2}{*}{$\begin{array}{l}\text { Foliage dry } \\
\text { matter (\%) }\end{array}$} & \multirow{2}{*}{$\begin{array}{c}\text { Number of } \\
\text { branches plant }^{-1}\end{array}$} \\
\hline Bio fertilizer & $\begin{array}{c}\text { Seaweed con. } \\
\mathrm{ml} / \mathrm{l}\end{array}$ & & Season 2017 & & \\
\hline \multirow{4}{*}{ Bio 0} & 0 & 50.871 & 34.801 & $19.41 \mathrm{a}$ & $3.11 \mathrm{~m}$ \\
\hline & 5 & $56.06 \mathrm{k}$ & $36.95 \mathrm{k}$ & $19.10 \mathrm{~b}$ & $3.27 \mathrm{k}$ \\
\hline & 10 & $58.76 \mathrm{j}$ & $39.03 \mathrm{j}$ & $18.81 \mathrm{c}$ & $3.42 \mathrm{j}$ \\
\hline & 0 & $76.15 \mathrm{c}$ & $64.55 \mathrm{de}$ & $14.11 \mathrm{k}$ & $3.91 \mathrm{bc}$ \\
\hline \multirow[t]{2}{*}{ Bio1 } & 5 & $78.06 \mathrm{~b}$ & $66.85 \mathrm{bc}$ & $14.02 \mathrm{k}$ & $3.95 \mathrm{ab}$ \\
\hline & 10 & $79.49 \mathrm{a}$ & $69.14 \mathrm{a}$ & 13.881 & $3.98 \mathrm{a}$ \\
\hline \multirow{3}{*}{ Bio 2} & 0 & $72.01 \mathrm{de}$ & $63.23 \mathrm{e}$ & $15.58 \mathrm{~h}$ & $3.80 \mathrm{ef}$ \\
\hline & 5 & $75.92 \mathrm{c}$ & $65.52 \mathrm{~cd}$ & $15.27 \mathrm{i}$ & $3.84 \mathrm{de}$ \\
\hline & 10 & $77.78 \mathrm{~b}$ & $68.13 \mathrm{ab}$ & $15.01 \mathrm{j}$ & $3.89 \mathrm{~cd}$ \\
\hline \multirow{3}{*}{ Bio3 } & 0 & $60.92 \mathrm{i}$ & $43.17 \mathrm{i}$ & $17.61 \mathrm{~d}$ & 3.191 \\
\hline & 5 & $65.28 \mathrm{~h}$ & $48.42 \mathrm{~h}$ & $17.21 \mathrm{e}$ & $3.30 \mathrm{k}$ \\
\hline & 10 & $68.51 \mathrm{~g}$ & $50.22 \mathrm{gh}$ & $17.01 \mathrm{f}$ & $3.49 \mathrm{i}$ \\
\hline \multirow{3}{*}{ Bio 4} & 0 & $69.73 \mathrm{f}$ & $49.84 \mathrm{gh}$ & $16.04 \mathrm{~g}$ & $3.62 \mathrm{~h}$ \\
\hline & 5 & $71.44 \mathrm{e}$ & $51.28 \mathrm{~g}$ & $15.98 \mathrm{~g}$ & $3.72 \mathrm{~g}$ \\
\hline & 10 & $72.87 \mathrm{~d}$ & $56.85 \mathrm{f}$ & $15.02 \mathrm{j}$ & $3.79 \mathrm{f}$ \\
\hline \multicolumn{6}{|c|}{ Season 2018} \\
\hline \multirow{3}{*}{ Bio 0} & 0 & $51.42 \mathrm{i}$ & $34.98 \mathrm{i}$ & $19.02 \mathrm{a}$ & $3.17 \mathrm{~m}$ \\
\hline & 5 & $56.99 \mathrm{~h}$ & $36.91 \mathrm{i}$ & $19.03 \mathrm{a}$ & $3.29 \mathrm{k}$ \\
\hline & 10 & $58.28 \mathrm{~h}$ & $45.49 \mathrm{gh}$ & $18.20 \mathrm{~b}$ & $3.41 \mathrm{j}$ \\
\hline \multirow{3}{*}{ Bio1 } & 0 & $76.30 \mathrm{~b}$ & $64.58 \mathrm{bc}$ & $14.31 \mathrm{i}$ & $3.84 \mathrm{bc}$ \\
\hline & 5 & $77.75 \mathrm{a}$ & $66.62 \mathrm{ab}$ & $13.99 \mathrm{j}$ & $3.94 \mathrm{ab}$ \\
\hline & 10 & $78.76 \mathrm{a}$ & $68.64 \mathrm{a}$ & $13.86 \mathrm{j}$ & $3.98 \mathrm{a}$ \\
\hline \multirow{3}{*}{ Bio 2} & 0 & $70.72 \mathrm{~d}$ & $61.41 \mathrm{c}$ & $15.66 \mathrm{~g}$ & $3.82 \mathrm{ef}$ \\
\hline & 5 & $75.56 \mathrm{~b}$ & $65.21 \mathrm{~b}$ & $15.44 \mathrm{~g}$ & $3.85 \mathrm{de}$ \\
\hline & 10 & $77.67 \mathrm{a}$ & $67.52 \mathrm{ab}$ & $15.10 \mathrm{~h}$ & $3.87 \mathrm{~cd}$ \\
\hline \multirow{3}{*}{ Bio3 } & 0 & $60.83 \mathrm{~g}$ & $43.83 \mathrm{~h}$ & $17.77 \mathrm{c}$ & 3.251 \\
\hline & 5 & $63.98 \mathrm{f}$ & $47.95 \mathrm{fg}$ & $17.17 \mathrm{~d}$ & $3.32 \mathrm{k}$ \\
\hline & 10 & $68.88 \mathrm{e}$ & $49.41 \mathrm{f}$ & $16.9 \mathrm{e}$ & $3.50 \mathrm{i}$ \\
\hline \multirow{3}{*}{ Bio 4} & 0 & $69.71 \mathrm{de}$ & 50.46 ef & $16.18 \mathrm{f}$ & $3.63 \mathrm{~h}$ \\
\hline & 5 & $70.98 \mathrm{~d}$ & $53.16 \mathrm{de}$ & $16.04 \mathrm{f}$ & $3.72 \mathrm{~g}$ \\
\hline & 10 & $72.60 \mathrm{c}$ & $55.84 \mathrm{~d}$ & $14.95 \mathrm{~h}$ & $3.78 \mathrm{f}$ \\
\hline
\end{tabular}

Control: without inoculation by bio-fertilizers.

Bio 1: A mixture of genera Bacillus, Azotobacter, Azospirllum and Rhizobium

Bio 3: A mixture of Azotobacter chroococcum and Azospirillum barsilense.
Bio 2: A mixture of multi- strains of Azotobacter

Bio 4: A mixture of Colstriedum, Azospirllum and Rhizobium

*Values marked with same alphabetical letter(s), within a comparable group of means, do not significantly differ, using revised L.S.D. test at 0.05 level.

\section{Yield and its components}

Concerning the effects of bio fertilizer types and seaweed extract concentrations on the yield and its components of pea plants, the results in Figures (3-4) clearly showed that the total pea yield and its parameters were significantly affected by the bio-fertilizers inoculation. The maximum total yield and its components expressed as the number of pods plant ${ }^{-1}$, average weight of pods plant $^{-1}$, shelling ratio $\%$, were obtained by using Bio 1 (mixture from Bacillus, Azotobacter, Azospirllum and Rhizobium), in both growing seasons. The increase in yield attribute and pod 
yield might be due to active and rapid multiplication of bacteria especially in rhizosphere creating favourable condition for $\mathrm{N}$ fixation at higher rate through supply by $\mathrm{N}$ fertilizers and supply of other nutrients, bacterial secretion, hormone production and supply of antibacterial and antifungal compounds of which favourable for growth and ultimately yield Saghafi et al. 2018.

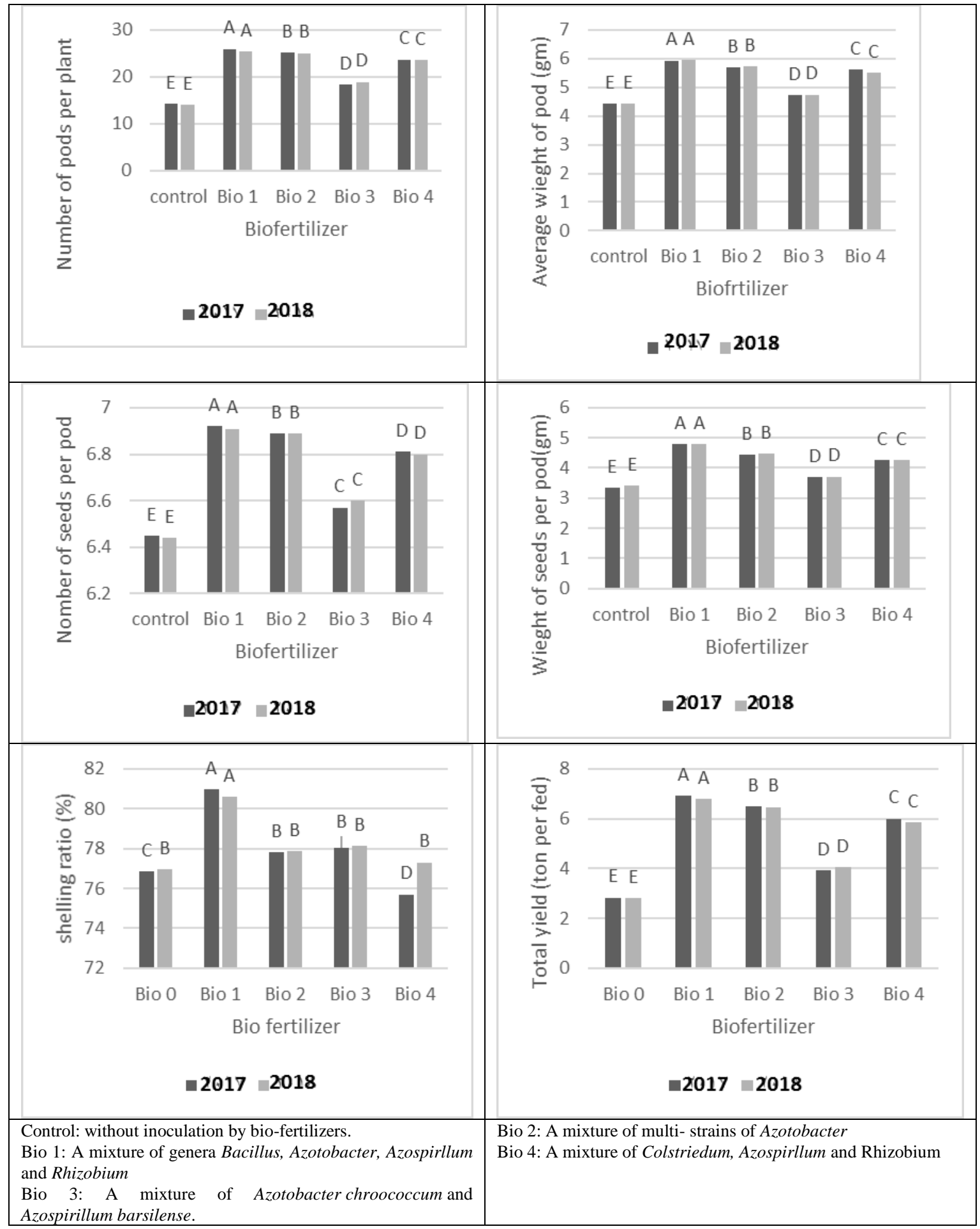

Fig. 3. Effect of bio- fertilizer on yield and its components in winter seasons 2017 and 2018 

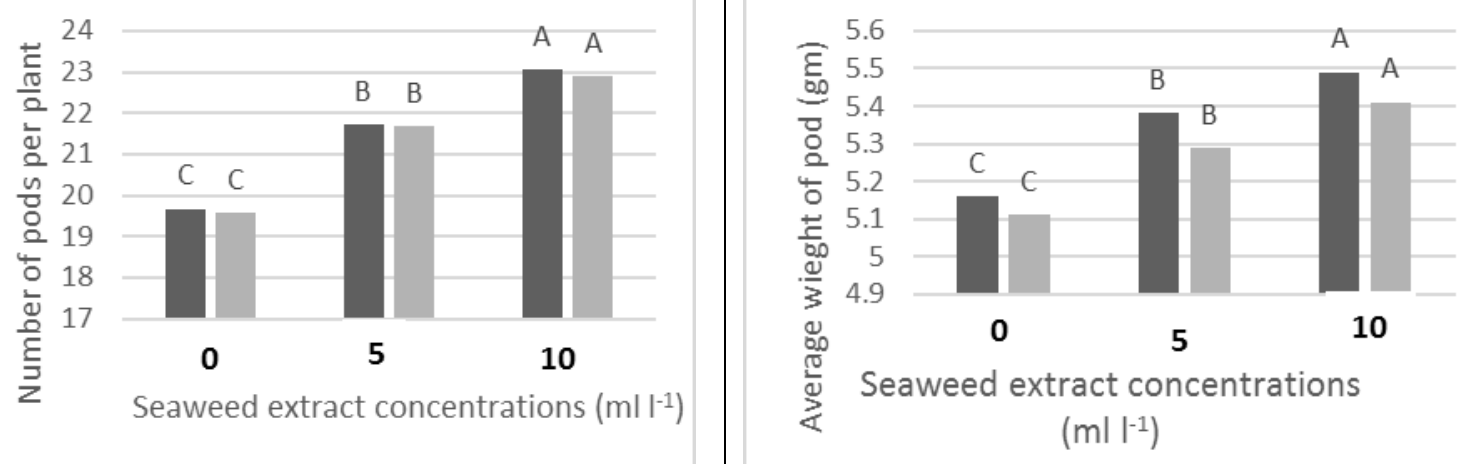

$\square 017 \quad 2018$
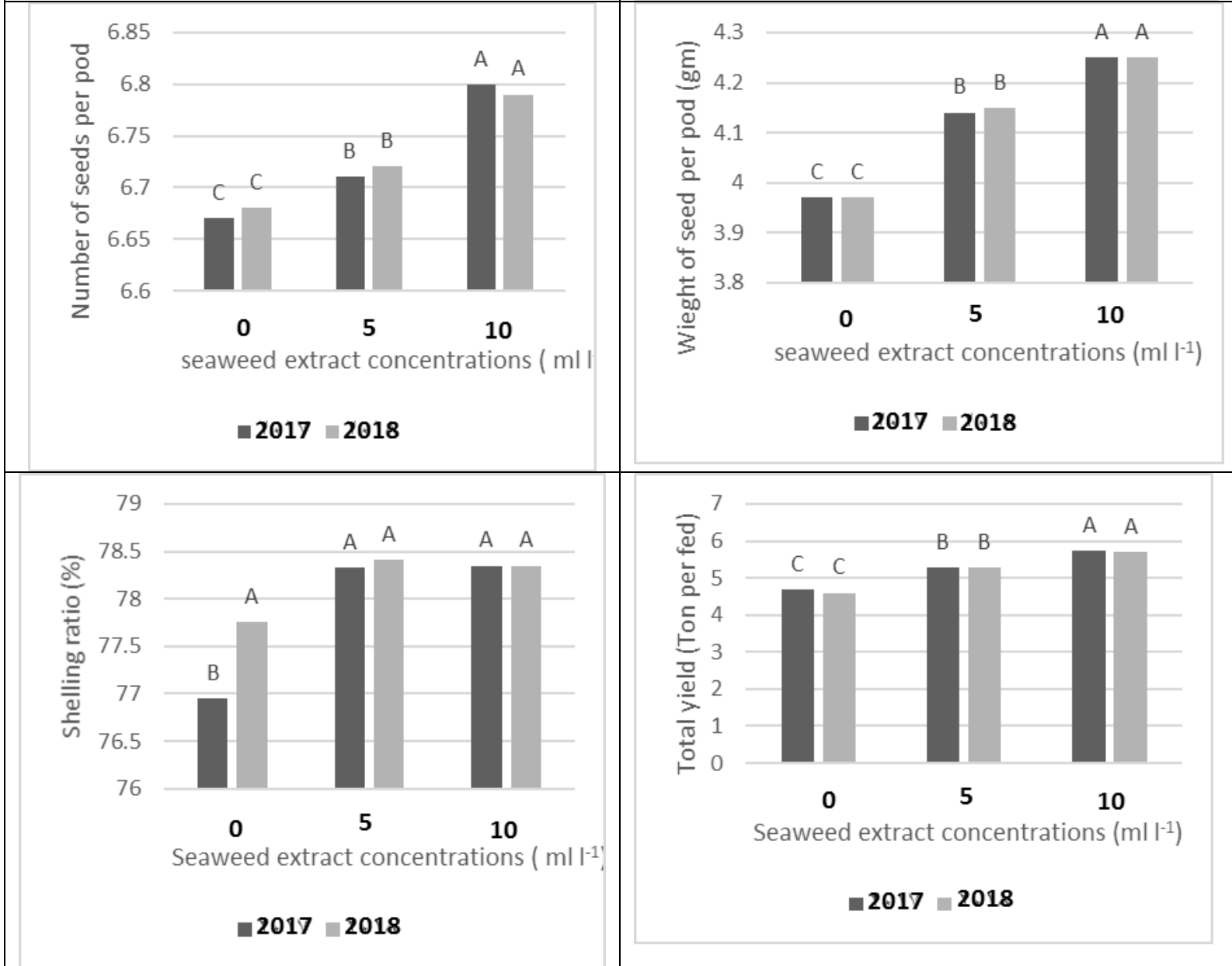

Fig .4. Effect seaweed extract on yield and its components in winter seasons 2017 and 2018 
Table 4. The interaction effects between bio fertilizer and seaweed extract on yield and its components in winter seasons 2017 and 2018

\begin{tabular}{|c|c|c|c|c|c|c|c|}
\hline Trea & nents & \multirow{2}{*}{$\begin{array}{c}\text { Number of } \\
\text { pods } \\
\text { plant }^{-1}\end{array}$} & \multirow{2}{*}{$\begin{array}{c}\text { Average } \\
\text { pod } \\
\text { weight } \\
(\mathrm{gm}) \\
\end{array}$} & \multirow{2}{*}{$\begin{array}{c}\text { Number of } \\
\text { seeds } \\
\text { pod }^{-1}\end{array}$} & \multirow{2}{*}{$\begin{array}{c}\text { seeds weight } \\
\text { pod }^{-1} \\
\text { (gm) }\end{array}$} & \multirow{2}{*}{$\begin{array}{l}\text { Shelling } \\
\text { ratio }(\%)\end{array}$} & \multirow{2}{*}{$\begin{array}{l}\text { Total yield } \\
\left(\text { ton } \text { fed }^{-1}\right)\end{array}$} \\
\hline $\begin{array}{c}\text { Bio } \\
\text { fertilizer }\end{array}$ & $\begin{array}{c}\text { Seaweed } \\
\text { con. } \\
\mathrm{ml} / \mathrm{l}\end{array}$ & & & & & & \\
\hline \multirow{3}{*}{ Bio 0} & 0 & $12.93 \mathrm{k}$ & $4.30 \mathrm{k}$ & $6.40 \mathrm{a}$ & $3.34 \mathrm{a}$ & $77.56 \mathrm{~d}-\mathrm{f}$ & $2.50 \mathrm{j}$ \\
\hline & 5 & $14.34 \mathrm{j}$ & $4.46 \mathrm{j}$ & $6.46 \mathrm{a}$ & $3.41 \mathrm{a}$ & $76.53 \mathrm{fg}$ & $2.87 \mathrm{i}$ \\
\hline & 10 & $15.30 \mathrm{ij}$ & $4.53 \mathrm{i}$ & $6.50 \mathrm{a}$ & $3.47 \mathrm{a}$ & $76.50 \mathrm{fg}$ & $3.12 \mathrm{hi}$ \\
\hline \multirow{3}{*}{ Bio1 } & 0 & $24.23 \mathrm{de}$ & $5.84 \mathrm{c}$ & $6.88 \mathrm{a}$ & $4.65 \mathrm{a}$ & $79.68 \mathrm{bc}$ & $6.36 \mathrm{c}$ \\
\hline & 5 & $26.13 \mathrm{bc}$ & $5.92 \mathrm{~b}$ & $6.90 \mathrm{a}$ & $4.79 \mathrm{a}$ & $80.86 \mathrm{~b}$ & $6.96 \mathrm{~b}$ \\
\hline & 10 & $27.50 \mathrm{a}$ & $6.04 \mathrm{a}$ & $7.00 \mathrm{a}$ & $4.98 \mathrm{a}$ & $82.36 \mathrm{a}$ & $7.48 \mathrm{a}$ \\
\hline \multirow{3}{*}{ Bio 2} & 0 & $23.62 \mathrm{e}$ & $5.53 \mathrm{f}$ & $6.85 \mathrm{a}$ & $4.21 \mathrm{a}$ & $76.09 \mathrm{~g}$ & $5.88 \mathrm{~d}$ \\
\hline & 5 & $25.40 \mathrm{c}$ & $5.74 \mathrm{~d}$ & $6.87 \mathrm{a}$ & $4.51 \mathrm{a}$ & $78.52 \mathrm{c}-\mathrm{e}$ & $6.56 \mathrm{c}$ \\
\hline & 10 & $26.73 \mathrm{ab}$ & $5.84 \mathrm{c}$ & $6.97 \mathrm{a}$ & $4.60 \mathrm{a}$ & $78.82 \mathrm{~cd}$ & $7.02 \mathrm{~b}$ \\
\hline \multirow{3}{*}{ Bio3 } & 0 & $15.56 \mathrm{i}$ & $4.63 \mathrm{~h}$ & $6.51 \mathrm{a}$ & $3.60 \mathrm{a}$ & $77.64 \mathrm{~d}-\mathrm{f}$ & $3.24 \mathrm{~h}$ \\
\hline & 5 & $19.06 \mathrm{~h}$ & $4.67 \mathrm{~h}$ & $6.54 \mathrm{a}$ & $3.70 \mathrm{a}$ & $79.17 \mathrm{c}$ & $4.00 \mathrm{~g}$ \\
\hline & 10 & $20.51 \mathrm{~g}$ & $4.92 \mathrm{~g}$ & $6.66 \mathrm{a}$ & $3.81 \mathrm{a}$ & $77.33 \mathrm{e}-\mathrm{g}$ & $4.54 \mathrm{f}$ \\
\hline \multirow{3}{*}{ Bio 4} & 0 & $21.96 \mathrm{f}$ & $5.49 \mathrm{f}$ & $6.74 \mathrm{a}$ & $4.05 \mathrm{a}$ & $73.77 \mathrm{~h}$ & $5.42 \mathrm{e}$ \\
\hline & 5 & $23.76 \mathrm{e}$ & $5.66 \mathrm{e}$ & 6.79.a & $4.33 \mathrm{a}$ & $76.56 \mathrm{fg}$ & $6.05 \mathrm{~d}$ \\
\hline & 10 & $25.34 \mathrm{~cd}$ & $5.74 \mathrm{~d}$ & $6.89 \mathrm{a}$ & $4.40 \mathrm{a}$ & $76.77 \mathrm{fg}$ & $6.54 \mathrm{c}$ \\
\hline \multicolumn{8}{|c|}{ Season 2018} \\
\hline \multirow{4}{*}{ Bio 0} & 0 & $13.01 \mathrm{i}$ & $4.32 \mathrm{~g}$ & $6.40 \mathrm{a}$ & $3.34 \mathrm{a}$ & $77.26 \mathrm{f}-\mathrm{h}$ & $2.53 \mathrm{j}$ \\
\hline & 5 & $14.17 \mathrm{~h}$ & $4.47 \mathrm{fg}$ & $6.45 \mathrm{a}$ & $3.42 \mathrm{a}$ & $76.58 \mathrm{~h}$ & $2.85 \mathrm{ij}$ \\
\hline & 10 & $14.87 \mathrm{~h}$ & $4.51 \mathrm{fg}$ & $6.48 \mathrm{a}$ & $3.47 \mathrm{a}$ & $77.03 \mathrm{gh}$ & $3.02 \mathrm{i}$ \\
\hline & 0 & $23.20 \mathrm{~d}$ & $5.85 \mathrm{a}-\mathrm{c}$ & $6.87 \mathrm{a}$ & $4.61 \mathrm{a}$ & $78.86 \mathrm{~cd}$ & $6.11 \mathrm{de}$ \\
\hline \multirow[t]{2}{*}{ Bio1 } & 5 & $25.83 \mathrm{bc}$ & $5.95 \mathrm{ab}$ & $6.88 \mathrm{a}$ & $4.79 \mathrm{a}$ & $80.57 \mathrm{~b}$ & $6.92 \mathrm{~b}$ \\
\hline & 10 & $27.12 \mathrm{a}$ & $6.02 \mathrm{a}$ & $7.01 \mathrm{a}$ & $4.95 \mathrm{a}$ & $82.33 \mathrm{a}$ & $7.34 \mathrm{a}$ \\
\hline \multirow{3}{*}{ Bio 2} & 0 & $23.41 \mathrm{~d}$ & $5.57 \mathrm{~d}$ & $6.85 \mathrm{a}$ & $4.27 \mathrm{a}$ & $76.65 \mathrm{~h}$ & 5.86 \\
\hline & 5 & $25.36 \mathrm{c}$ & $5.75 \mathrm{~b}-\mathrm{d}$ & $6.88 \mathrm{a}$ & $4.53 \mathrm{a}$ & $78.74 \mathrm{c}-\mathrm{e}$ & $6.56 \mathrm{c}$ \\
\hline & 10 & $26.42 \mathrm{ab}$ & $5.87 \mathrm{a}-\mathrm{c}$ & $6.94 \mathrm{a}$ & $4.59 \mathrm{a}$ & $78.25 \mathrm{~d}-\mathrm{g}$ & $6.97 \mathrm{~b}$ \\
\hline \multirow{3}{*}{ Bio3 } & 0 & $16.63 \mathrm{~g}$ & $4.64 \mathrm{f}$ & $6.54 \mathrm{a}$ & $3.60 \mathrm{a}$ & $77.58 \mathrm{e}-\mathrm{h}$ & $3.47 \mathrm{~h}$ \\
\hline & 5 & $18.99 \mathrm{f}$ & $4.67 \mathrm{f}$ & $6.63 \mathrm{a}$ & $3.71 \mathrm{a}$ & $79.58 \mathrm{bc}$ & $3.99 \mathrm{~g}$ \\
\hline & 10 & $21.14 \mathrm{e}$ & $4.95 \mathrm{e}$ & $6.64 \mathrm{a}$ & $3.82 \mathrm{a}$ & $77.23 \mathrm{f}-\mathrm{h}$ & $4.70 \mathrm{f}$ \\
\hline \multirow{3}{*}{ Bio 4} & 0 & $21.56 \mathrm{e}$ & $5.18 \mathrm{e}$ & $6.73 \mathrm{a}$ & $4.03 \mathrm{a}$ & $78.41 \mathrm{c}-\mathrm{f}$ & $5.03 \mathrm{f}$ \\
\hline & 5 & $24.03 \mathrm{~d}$ & $5.64 \mathrm{~cd}$ & $6.77 \mathrm{a}$ & $4.32 \mathrm{a}$ & $76.61 \mathrm{~h}$ & $6.10 \mathrm{e}$ \\
\hline & 10 & $24.94 \mathrm{c}$ & $5.73 \mathrm{~b}-\mathrm{d}$ & $6.89 \mathrm{a}$ & $4.41 \mathrm{a}$ & $76.91 \mathrm{~h}$ & $6.43 \mathrm{~cd}$ \\
\hline
\end{tabular}

Control: without inoculation by bio-fertilizers.

Bio 2: A mixture of multi- strains of Azotobacter

Bio 1: A mixture of genera Bacillus, Azotobacter, Azospirllum and Rhizobium

Bio 4: A mixture of Colstriedum, Azospirllum and Rhizobium

Bio 3: A mixture of Azotobacter chroococcum and Azospirillum barsilense.

*Values marked with same alphabetical letter(s), within a comparable group of means, do not

significantly differ, using revised L.S.D. test at 0.05 level.

These results are matched well with those achieved by Badr et al. (2014) who indicated that inoculated pea seeds with bio-fertilizer significantly surpassed on uninoculated ones in all yield components characters (i.e. a number of pod plant ${ }^{-1}$, seed as well as number of seed pod $^{-1}$, pods weight plant ${ }^{-1}$ ).
Concerning the effect of foliar application of seaweed extract in the two tested seasons (Figure 4), the obtained data showed that the foliar application of seaweed extract increased significantly (number of pods plant $^{-1}$, average weight of pods plant ${ }^{-1}$, number of seed $\operatorname{pod}^{-1}$, number of seed pod $^{-1}$, shelling ratio $\%$ ) and total pods yield (ton fed. ${ }^{-1}$ ) as compared with the control 
treatment. Respecting enhancing potential of the seaweed extract on the yield and its components might be due to supply pea plants with micro, macro nutrients and significant amounts of cytokinins, auxins and betaines, which increase chlorophyll production by boosting the photosynthetic process, thereby stimulating vegetative growth that would be improved accordingly and reflect on its productivity. These results are in harmony with the findings of Nour et al. (2010) on tomato, and Rathore et al. (2009) on soybean.

The interactions effects between varying types of bio-fertilizer and different concentrations of foliar application of seaweed extract, are presented in Table (4). The results illustrated that the plants treated with Bio (1) combined with foliar application of seaweed extract at the rate of $10 \mathrm{ml} \mathrm{l}^{-1}$ concentration achieved the highest values of the number of pods plant ${ }^{-1}$, average pod weight, shilling ratio (\%), and total pods yield (ton fed. $^{-1}$ ) as compared with other treatment combinations; in the two seasons.

\section{Chemical Components}

Results presented in Figures (5-6) showed the chemical constituents of pea green seeds as a response of bio-fertilizer types and various application concentrations of seaweed extract. Results clarified that the highest values of all estimated parameters, i.e. N, P, $\mathrm{K}$ and total protein in pea green seeds were observed in pea plants that inoculated with bio-fertilizers (1), in the two growing seasons.

The results, also, revealed that the foliar application of seaweed extract at the concentration of $10 \mathrm{ml} \mathrm{l}^{-1}$ increased significantly $(\mathrm{N}, \mathrm{P}, \mathrm{K} \%)$ and total protein contents in the pea green seeds, in the two tested seasons The superiority of seaweeds was due to the benefits of seaweed components providing an excellent source of bioactive compounds such as macro- and micronutrients, essential fatty acids, amino acids, vitamins, cytokinins, auxins like growth promoting substances affecting

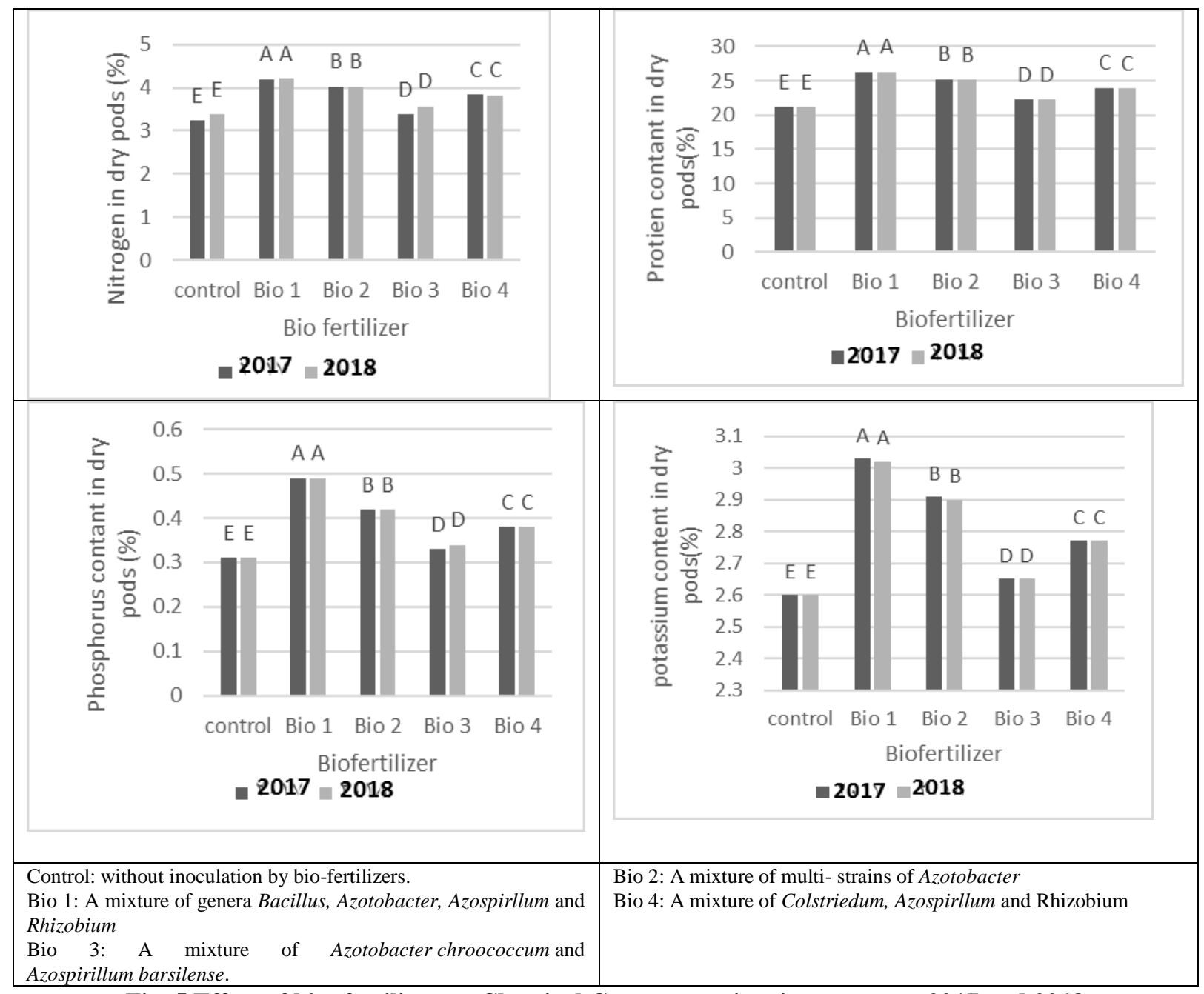

Fig .5.Effect of bio- fertilizer on Chemical Components in winter seasons 2017 and 2018 


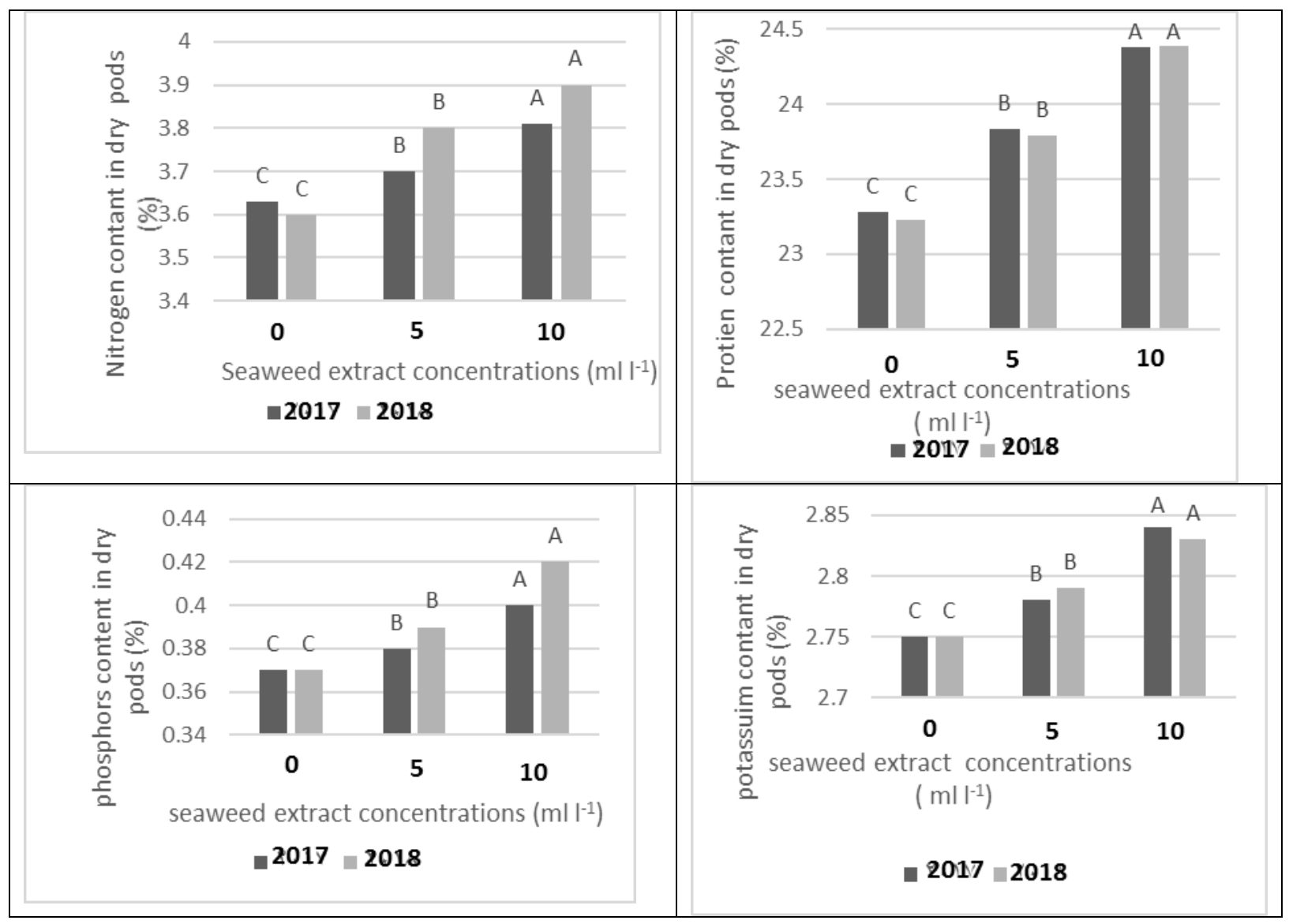

Fig.6.Effect seaweed extract Chemical Components in winter seasons 2017 and 2018 


\section{CONCLUSIONS}

It could be concluded from the results of this study that using a mixture of multi strain of diazotrophic bacteria as a biofertilizer (Rhizobium, Azotobacter, Azospirellum and Bacillus) . Moreover, foliar application of seaweed extract formula at concentration $10 \mathrm{ml} \mathrm{l}^{-1}$ that prepared from algae available widely in the Egyption coastal can be a very effective, applicable and cheap meathod for high productivity of pea plants. In addition, their effets are save on human health and environment.

\section{ACKNOWLEDGEMENT}

The authors is thankful to Dr. Nader Ashmawey Assistant Professor in Plant Pathology Department of Agriculture Faculty, Alexandria, University, Egypt for his valuable help in the microbiological assay carried out in the present study.

\section{REFERENCES}

Abd El-Baky, H.H., F. K. El Baz and G. S.E 1 Baroty.2008. Evaluation of Marine Alga Ulva lactuca L. as A Source of Natural Preservative Ingredient. American-Eurasian J. Agric. and Environ. Sci. 3(3): 434-444.

Aleem AA. 1993. The marine algae of Alexandria. Egypt. 139 pp. Privately published. Alexandria.

Badr, E. A., A. A. Bahr, G. A. Amin and A.M. Wali. 2014. Response of sugar pea to spraying with molybdenum, bio and nitrogen fertilizer on seed yield and quality. Mid. East. J. Agri. Res. 3(2):363-367.

Badry B. and M. Salim. 2016. Influence of biochar and seaweed extract applications on growth, yield and mineral composition of wheat (Triticum aestivum L.) under sandy soil conditions. Annals of Agricultural Science. 61(2):257-265.

Braune W. 2008. Meeresalgen. Ein Farbbildführer zu verbereit en Grün-. 596 pp Braun- und Rotalgen der Weltmeere Gantner Verlag Ruggell.

Co-State Software. 2004. User's manual version. Cohort Tusson, Arizona, USA. Davies, B.H. 1976. Analysis of carotenoid pigment. In: T. W. Goodwin (ed.), Chemistry and Biochemistry of Plant Pigments. Academic Press, London and New York.

Dawa, K. K., S.M. Farid and A.E. El-Bauomy .2014. Effect of bio-fertilizer inoculation method and some foliar application treatments on yield and quality of pea plants. J. Plant Production, Mansoura. Univ. 5(11): 1759 -1775.

De Bruijn, F.J. Hilgert, J. Stigter, M. Schneider, H. Meyer, U. Klosse, K. Pawlowski .1999. Regulation of nitrogen fixation and assimilation genes in the free-living versus symbiotic state. In: Gresshoff PM, Roth LE, Stacey G, Newton W (eds.) Nitrogen fixation: achievements and objectives. Chapman and Hall, New York and London. pp 33-44.
Evenhuis and P.W. Dewaard. 1980. Principles and practices in analysis. FAO Soils Bull.38:152-163.

Jagnow, G., G. Hoflich and K.H. Hoffman. 1991.Inoculation of non- symbiotic rhizosphere bacteria: Possibilities of increasing and stabilizing yields. Angew Botanik, 65:97126.

Kavipriya, R., P.K. Dhanalakshmi, S. Jayashree and N. Thangaraju. 2011. Seaweed extract as a biostimulant for legume crop, green gram. Journal of Ecobiotechnology 3(8): 16-19.

Khan, W., U. Rayirath, S. Subramanian, M. Jithesh. P. Rayorath, 1. M. Hodges, A. Critchley, J. Craigie, J. Norrie, B. Prithiviraj. 2009. Seaweed Extracts as Biostimulants of Plant Growth and Development, Journal of Plant Growth Regulation. 28(4):386-399.

Khan, W., U. P. Rayirath, S. Subramanian, M.N. Jithesh , P. Rayorath, D. Mark , A.T. Critchley , J. S. Craigie , J. Norrie , B. Prithiviraj. 2009. Seaweed extracts as biostimulants of plant growth and development .J Pla. Gro. Reg. 28:386-399.

Mishra, N. 2014. Growth and yield response of pea (pisum sativum L.) to Integrated Nutrient Management- A Review. J. Pla. And Pes. Sci. 1(2): 87-95.

Murphy, J. and J.P. Riley. 1962. A modified single solution method for the determination of phosphorus in natural water. Anal. Chim.Acta. 27:31-36.

Norrie, J. and J.P. Keathley .2006. Benefits of Ascophyllum nodosum marine-plant extract applications to 'Thompson seedless' grape production. (Proceedings of the Xth International Symposium on Plant Bioregulators in Fruit Production, ActaHortic .727:243-247.

Nour, K. A. M., N. T. S. Mansour and W. M. Abd El- Hakim .2010. Influence of foliar spray with seaweed extracts on growth, setting and yield of tomato during summer season, J. Plant Production, Mans. Uni. 1 (7): 961 - 976.

Oram, P.A. and M.Agcaolili. 1994. Current status and future trends in supply and demand of cool season food legumes. pp:-49(Ed): R.J. summer field, world crops: cool season food legumes .Kluwer Acad .Pub Dordreach,

Netherland

Ordog, V., W.A.Stirk, van J. Staden, O. Novak, M. Strnad, 2004. Endogenous cytokinins in the three genera of microalgae from the chlorophyta. J. Phycol. 40:88-95.

Ordog, V., W.A. Stirk, V. J. Staden, O. Novak and M. Strnad .2004. Endogenous cytokinins in the three genera of macroalgae from the chlorophyta. J .Phycol. 40:88-95.

Page, A.L., 1982. Methods of soil Analysis, Part2 : chemical and microbiogical properties . Amer.Soc. Agron.,Madison,Wisconsin,USA.

Pempkowiak, J., J. Kozuch and T. Southon .1994. The influence of structural features of marine humic substances on the accumulation rates of cadmium by a blue musselMytilusedulis, Environm. Int., 20: 291-395. 
Ramya, S. S., N. Vijayanand and S. Rathinavel. 2015. Foliar application of liquid bio-fertilizer of brown alga Stoechospermum marginatum on growth, biochemical and yield of Solanum melongena. Int. J. Rec. Org. Was. Agr. 4:167-173.

Rather S.A., M.H. Hussain and M.L. Sharma.2010.Effect of biofertilizers on growth yield and economics of field pea (Pisumsativum L.). Int. J. Agri. Sci. 6(1): 65-66.

Rathore, S. S., D. R. Chaudhary, G. N. Boricha, A. Ghosh, B. P. Bhatt,S.T. Zodape and J. S. Patolia. 2009. Effect of seaweed extract on the growth, yield and nutrient uptake of soybean (Glycine max) under rainfed conditions. Sou. Afri. J. Bot. 75(2):351-355.

Saghafi, D., M. Ghorbanpour and B. A. Lajayer. 2018.Efficiency of Rhizobium strains as plant growth promoting rhizobacteria on morpho-physiological properties of (Brassica napus L.) under salinity stress. J. Soi. Sci. \&Pla. Nut. 18 (1): 253-268.

Sarg, M.H. and M.A. Hassan .2003. Effect of Rhizobium inoculation, nitrogen fertilization and plant density on growth, yield and minerals content of pea under sandy soil conditions. J. Agric. Sci., Mansoura. Univ. 28 (11): 68576873 .
Solieman, T.H., H.A. El-Khatib and S.M. El-Araby. 2003. Effect of organic manure, mineral nitrogen and biofertilizer application on vegetative growth and chemical composition of pea (Pisumsativum, L.) Zag. J. Agri. Res. 30 (3): 751-767.

Spaink, H.P., A. Kondorosiand and P. J. Hooykaas .1998. The rhizobiaeceae. Kluwer, Dordrecht, The Netherlands.

Steel, R. G. D. and J. H. Torrie. 1984. Procedures of statistics ( $2^{\text {nd }}$ Edition), McGraw Hill Book Co. Inc. New York, USA.

Stirk, W.A., M.S.Novak and J. Van Staden. 2003. Cytokinins in macroalgae. Plant Growth Regul. 41:13-24.

Tagore, G.S., S.L. Namdeo, S.K. Sharma and N. Kumar .2013. Effect of Rhizobium and phosphate solubilizing bacterial inoculants on symbiotic traits, nodule legheamoglobin and yield of chickpea genotypes. Int. J. Agro. 58:16-27.

Zaghloul, R. A., H. E. Abou-Aly, R. M. El-Meihy and M.T. El-Saadony. 2015. Improvement of growth and yield of pea plants using integrated fertilization management. Universal Journal of Agricultural Research. 3(4): 135143.

\section{الملخص العربي \\ تأثير استخدام التسميد الحيوى ومستخلص الطحالب كمنشط حيوي على نمو وإنتاجية وجودة نباتات البسلة}

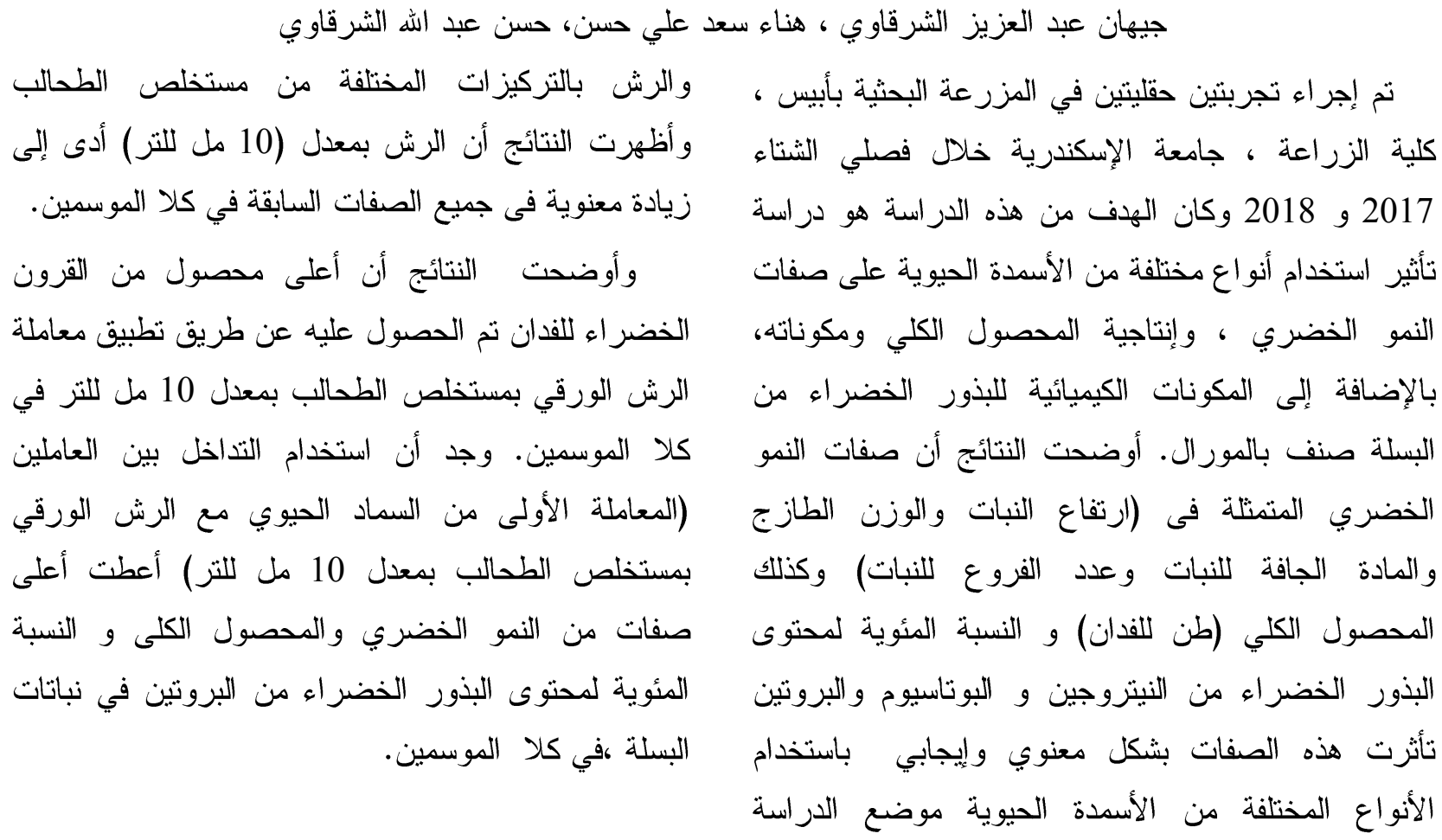

